\title{
Industrialization by Fitting in: Acquiring Technology through Collaboration and Subcontracting
}

\section{Sikander Rahim*}

\begin{abstract}
Since the 1950s, Pakistan has been trying to industrialize by investing in industries that have low value-added, notably cotton textiles. Here, low valueadded means that the export value of the cotton textiles less the value of the raw cotton used to make them was low relative to the cost of the investment needed to make the textiles, i.e., contrary to the usual assumption, cotton textile manufacture was capital-intensive. The cause was the protection of the importing countries. But goods with high value-added in this sense required advanced technical knowledge, which is mostly the proprietary knowledge of the firms whose research and development $(R \mathcal{E} D)$ has generated it. Over time, all the production of goods that do not require such technical knowledge has passed to low-wage countries whose mutual competition keeps the value-added low. Since Pakistan cannot compete in high-value-added goods, it must emulate the East Asian economies by collaborating with firms in high-wage countries-i.e., subcontracting them to make simple components - and progress through such collaboration to receiving the knowledge and training to making components with higher value-added.
\end{abstract}

Keywords: Pakistan, textiles, protection, value-added, subcontracting.

JEL classification: $\mathrm{O} 14$.

\section{Pakistan's Industrial Start}

Few would dispute that income growth in the long run has to be obtained through industrial development. At the same time, most would agree that there has been a fair amount of industrial development in Pakistan and that it has given rise to disappointingly little increase of income. A third point, one that most people would take as obvious, is that industry in Pakistan has, with few exceptions, been confined to activities that have low value-added and, hence, yield little income. This paper is an attempt to explain these assertions more fully, to describe Pakistan's industrialization in the past in this light, and to discuss alternative patterns of industrial development.

\footnotetext{
${ }^{*}$ Former Principal Economist, World Bank.
} 
At Partition in 1947, there was almost no industrial manufacture in Pakistan. Both East and West Pakistan were agricultural economies that exported some agricultural products to other areas. East Pakistan was the world's main grower of jute and, since the jute mills to which the crop used to go were in India, jute became an export-for many years Pakistan's main export. West Pakistan had become a provider of wheat to India in the $19^{\text {th }}$ century, but now exported little other than raw cotton.

Until the end of the Korean War (1950-53), there had been little effort to industrialize. It could not be expected in the early years. Besides, the war caused a commodity boom that allowed some prosperity and seemed to reduce the urgency for action in this respect. But the end of the war led to a fall in the prices of the commodities that Pakistan had been exporting, and the ensuing shortage of foreign exchange was so severe that it seemed that there was no alternative to industrializing quickly. Export receipts fell to a fraction of what they had been and imports had to be reduced accordingly. To the political leaders and government officials, it was obvious that industry had to begin with the raw materials at hand; instead of exporting raw cotton and jute, Pakistan should produce cotton textiles and jute bags.

With cotton this was simple. Virtually all cotton textiles were imported or hand woven. By banning textile imports in 1954, any new textile mills were assured a market with high prices. At first, the scarcity of cotton textiles was so great that new mills recovered their costs in one or two years. The government tried to temper the scarcity pricing with price controls, it seems, with some success, but it also wanted the investment to be so profitable that it would generate a new industrial entrepreneurship. As to be expected, the demand to invest in cotton manufacturing was well in excess of what could be met; since all the plant and machinery had to be imported, the investment was constrained by the shortage of foreign exchange.

Jute could not provide a similarly profitable market for longunlike cotton goods, jute goods were not a necessity of daily life, and there was small scope for substituting domestically made jute bags for imported bags. Moreover, a scarcity of jute bags and high prices would have affected farmers and other producers. Jute manufacture did not, therefore, have the same attractiveness as cotton in the first stages.

In theory, the substitution of domestically made cotton textiles for imports saved foreign exchange equal to the value-added from transforming the cotton that would otherwise have been exported. This should have relieved the scarcity of foreign exchange and allowed the investment to 
continue. In practice, it did not. By 1957, the foreign exchange scarcity had become extreme and the country was close to defaulting on its external payments, despite the severity of the foreign exchange rationing.

There were two reasons for this. One, which is no longer relevant but was tragic at the time, was the destruction of the handloom sector. Modern power looms did not just replace imports; they put the handloom weavers, who had been providing a large part of the domestic supply of cotton cloth, out of work. These weavers' looms were made entirely in the country of local raw materials and had no discernible foreign exchange cost. Since foreign exchange was, at the time, the binding constraint to increases in textile production-to the extent that power loom production displaced handloom production rather than imports-there was no saving of foreign exchange or gain of production and income.

It would be plausible to argue that the handloom weavers were displaced because they could not compete with the power looms on price. But this seems not to have been true. The mere fact that they had plied their trade in large numbers until then, despite the liberal import of textiles and the lower rupee prices before 1954, is evidence that they could compete. There were official enquiries into the situation of the handloom sector and analyses of its costs ${ }^{1}$ that indicate that handloom weaving was competitive on price. Moreover, there had been some technical progress in the design of handlooms, since they had been so important and widespread in the Subcontinent, and, apart from the traditional handlooms, more advanced designs with greater output were available. One difficulty the weavers faced at the time, according to some of the reports, was obtaining yarn. Handloom spinning, though still common in the Subcontinent, could not meet demand, and machine-spun yarn was kept for the power looms. Another difficulty of the weavers was obtaining dyes, which were mainly imported. Within a few years the handlooms had virtually disappeared, at least around the towns, and weavers had to find work in the modern mills.

The second reason that the foreign exchange shortages persisted was that cotton manufacture yielded little more foreign exchange than raw cotton. The value-added in terms of foreign exchange-meaning the amount by which the foreign exchange value of the manufacture exceeded that of the raw cotton and other traded inputs needed for it, such as dyes, bleach, and fuel-was low in relation to the foreign exchange cost of the investment, i.e., the plant and machinery that had to be imported.

\footnotetext{
${ }^{1}$ Several documents of this kind were in the library of the Pakistan Institute of Development Economics (PIDE) in 1968.
} 
Comparing this value-added to the foreign exchange cost of the investment gives the equivalent of a capital-output ratio. A high capital-output ratio means the activity is capital-intensive. As a rule, the capital-output ratio of an industry suited to a country like Pakistan, with little capital and much unemployed labor, was considered to be around 2 or 3 . Estimates for various years from 1954 to $1959 / 60$ of the capital-output ratio as defined here vary from 7 to 14 , depending on the year and the relative prices of cotton and cloth that year. That this was purely the result of protection can be seen from comparison with calculation using British prices for the same types of cloth, which gives a ratio of 2.5 .

The reasons for the low value-added were obvious: When Pakistan exported textiles, the countries to which the exports went had their own textile industries to protect and used tariffs and quotas to protect them. This was not just true of Pakistan or of cotton textiles, but held for practically all manufactures and agricultural products that the low-wage countries exported to the high-wage countries of Western Europe and North America. In the case of cotton, the importing countries put tariffs on the manufactures but not on the raw cotton. They lowered the price the exporter received below that of the competing domestic producer by the amount of the tariff, without lowering the price of the raw cotton. In all the importing countries, competition among textile manufacturers was not lacking, nor did there seem to have been oligopolies or cartels, so the prices the exporters received were not inflated by lack of competition. Nonetheless the cotton textile lobbies in the importing countries were obviously effective in obtaining protection.

This protection of their cotton manufacture by high-wage countries contravened the General Agreement on Tariffs and Trade (GATT), which allowed only temporary protection against market disruption. It began in the mid-1950s and was formalized in the ShortTerm Cotton Textile Arrangement. This was followed in 1960 by the Long-Term Arrangement, and then in 1965 by the Multi-Fibre Agreement (MFA), which extended the protection to fibers other than cotton. Only in 2005 did the MFA come to an end, although countries have been allowed to continue some of their protection.

\section{Mistaken Comparative Advantage}

This raises three questions. First, why did economists and planners, at least in Pakistan, not take account of the protection against the country's main export? Second, what have the consequences for the economy been and, third, what does it imply for future economic development? 
The answer to the first question is, simply, dogma. Pakistan was a poor country with little capital and much unemployment, textiles were supposed to be a labor-intensive industry, and theory dictated that the country's comparative advantage lay in labor-intensive activities. Moreover, the raw material was produced in the country and the technical level was elementary compared to most manufacturing in high-wage countries. Had economic advisors actually calculated the ratio of the valueadded that Pakistan received against the foreign exchange cost of the investment, they would have discovered that textile manufacture was an exceptionally capital-intensive industry.

There was no incentive for the planners and their advisors to examine the economic productivity of cotton manufacturing more closely, because the industry was profitable enough that the demand to invest in it during the 1960s was constrained only by the scarcity of foreign exchange. But the profitability was artificial. Profit was subsidized through the Export Bonus Scheme (EBS), started in 1959, best known as the bonus voucher system. Under this system, an exporter of cotton manufactures received vouchers that entitled the bearer to buy foreign exchange at the official rate, which was then PRs 4.76 to the US dollar. The vouchers could be sold on the market and the price was, in effect, a premium over the official exchange rate. They were issued for a variety of manufactured exports in proportion to the foreign exchange received, the proportion varying according to the type of export in the range of 10-40 percent, the "bonus rate." Most of the time, the premium varied between 150 and 180 percent. So, a cotton exporter getting a bonus rate of 30 percent when the premium was 150 percent received an additional 45 percent of the rupee value of the export. This was entirely profit because the raw cotton and other traded inputs were exported or imported at the official exchange rate, and was a subsidy paid by those who used bonus vouchers for imports.

Originally, the EBS, which was similar to the exchange certificate scheme used in Taiwan a few years before, had been recommended as an emergency measure; the mistake was to make it permanent. Pakistan's economy was in trouble by 1957 because of the shortage of foreign exchange and the EBS was proposed by a German advisor to stimulate exports quickly, although he emphasized that it was a short-term expedient and had to be temporary. But the temptation of inflating profits so easily was too great. Moreover, the EBS solved the problem of how to make jute manufacturing equally profitable. Something could, therefore, be done for East Pakistan. The scheme thus became permanent and was only ended in 1972, with the new official exchange rate of PRs 9.91 to the US dollar. 
If the industrial policy had been as successful as it appeared to be, Pakistan would gradually have overcome its shortage of foreign exchange and would not have been permanently in need of foreign aid. An indication of how little was achieved in terms of generating income in relation to the investment involved is that in no year before 1970 was the dollar value of exports as much as in 1950/51. The economy continued to depend on foreign aid and its external debt service increased; by 1968, the last year of Ayub Khan's government, it was 18 percent of exports.

In some respects, Pakistan was typical of the low-wage countries in following the advice it received, that it should adhere to its comparative advantages and invest in labor-intensive industries to export to the highwage countries despite the elaborate system of tariffs and quotas the latter imposed on the former's exports. Many development economists and government officials deplored the protectionism of the high-wage countries, but the explanation that influential economists of the time, such as Bela Balassa and Anne Krueger, put forward for the difficulties of the low-wage countries was their own protectionism. They asserted that these countries' production was inefficient because their industries were protected too much against international competition, a conclusion they reached by comparing the countries' value-added at "world prices" with the value-added at domestic prices, the ratio of the latter to the former being the "effective protection rate" (EPR). Calculating EPRs for different industrial activities in a variety of countries became a common exercise among economists and they were nearly always found to be greater than 1 , which was interpreted as a sign of inefficiency and "rent seeking", because, in their theory, efficient producers would be competitive at world prices and have EPRs not greater than 1.

The procedure for calculating EPRs had two defects that made them misleading. One was the way the so-called "world prices" were found. Limiting this discussion to the case of most interest to the economy at the time, its jute and cotton manufactures, they were the export unit values (i.e., the value of the exports in a given period as given by the export statistics divided by the quantity of those exports). This took no account of the effect the protection of the importing countries had in lowering the prices the exporters received below those received by competing producers in high-wage countries. There seem to have been no studies of effective protection that used the prices of the high-wage country producers for world prices. Unless the domestic prices in the exporting country were to be below the export unit values, the EPRs were sure to be greater than 1 and, while the EBS lasted, the domestic prices of textiles were naturally higher by the amount of the subsidy. 
The second defect was the assumption that, when the value-added in a manufacturing activity at domestic prices was higher than that at world prices, it was a sign of inefficiency. No attempts were made to corroborate the conclusion by collecting the physical data from factories. Such data as is available indicates no such inefficiency. ${ }^{2}$ Effective protection is not a criterion for the physical or economic efficiency of production. Physical efficiency has to be determined from factory data and economic efficiency has to be measured as the value-added in relation to the investment needed to produce it. Pakistan's cotton and jute factories were physically efficient enough to compete with the factories of the high-wage countries despite trade barriers, but they were economically inefficient because of the trade barriers.

\section{Some Economic Consequences of Protection by High-Wage Countries}

Since the protectionism of the high-wage countries occurred at the beginning of most low-wage countries' attempts at economic development, it determined much of what happened to these economies later. Some of the consequences are described briefly here.

The first is that almost all textile production has been transferred to the low-wage countries, but the transfer was gradual. The exceptions are some high-quality goods requiring special skills and articles dependent on fashion design specific to the producers. Because the transfer was so gradual, with the various "Arrangements" spread over roughly half a century, the bankruptcies and unemployment that free trade would have caused in the high-wage countries were mostly avoided. The textile industries could disappear slowly and their employees could find other work or retire.

This has had a second consequence, namely, to make textile production a low-value-added activity. It was pointed out above that it always was a low-value-added activity whilst Pakistan exported textiles, but it had a higher value-added in the high-wage countries. Textile producers in the latter had to pay workers nominal wages that were many times the nominal wage in Pakistan, which is why they needed trade protection. The difference in value-added or income between that from producing in Pakistan and that from producing in the high-wage countries was the tariff revenue collected by the importing countries or the extra profit made by importers by lowering prices caused by import quotas (Gresser, 2002). ${ }^{3}$ Now it is, with the exceptions mentioned, purely a lowvalue-added activity in which producers in a number of low-wage countries, including Bangladesh, China, Egypt, and India compete.

\footnotetext{
${ }^{2}$ See Zaidi (1999, pp. 94-95) who quotes Asad Sayeed's calculations of total factor productivity growth.

${ }^{3}$ What he finds for the US is also true for Western Europe.
} 
Another consequence, following from the earlier profitability of investment in Pakistan, was the neglect of education, especially in science and engineering. Apart from the industries that were highly profitable because of the EBS, some manufacturing was set up to cater to the domestic market with high levels of protection and also required some basic engineering knowledge. Making light bulbs, water pumps, and electric fans involved no technical knowledge that was not readily available, and the capital equipment was imported. Easy profits from simple manufacturing processes of this sort concealed the need to be able to move on to more complex industrial activities. So, when the apparently rapid industrial growth of Ayub Khan's period came to an end, all the industry in the country consisted of this type of simple manufacture and the education system continued to be neglected. This is not to say that the neglect was merely economic, but the social and political complexities behind it are beyond the scope of this article. It suffices to stress two points. One is that these complexities might have had a different result if industrialization had been less easily profitable and, thus, had made the need for a better education system felt. The other is that the desire for education was there-almost all families wanted their children to have an education-but few could afford it and the state did too little.

Finally, the outcome has been failure to diversify out of simple manufacturing; the range of industrial products has not changed much from that of 1968. There has been an improvement of quality in some activities, for instance, surgical instruments (see Chaudhry, 2005; Nadvi 1999), and there has been growth in the production of machinery for textiles and diesel engines, but all these remain by the standards of the present, simple manufactures and, considering the time it has taken, these are modest results.

The example of textiles shows why it is so difficult for low-wage countries to find goods to manufacture that have a high value-added when imported or exported. If low-wage country producers can produce a good that is produced in high-wage countries, they can obtain the same valueadded as high-wage country producers if trade is free, with bigger profit margins making up for lower wage costs. Since low-wage country producers can always lower their prices slightly below those of their highwage country competitors and still have bigger profit margins, they eventually drive these competitors out of business. At that point, with no more high-wage competitors to displace, the competition is among lowwage producers and profit margins fall. Then the good becomes a lowvalue-added good. In the case of textiles and many other articles that lowwage countries manufactured from the 1950s to the 1990s, the process was slowed by the protectionism of the high-wage countries, and low-wage 
country producers never received the high value-added they would have received with free trade.

Now the problem of the low-wage country producers is to find other goods that they can start producing and for which they can obtain a high value-added. Here, a high value-added implies that the value-added in foreign exchange received from exporting or that saved by substituting for imports is high in relation to the cost of the investment. Such goods have the special characteristic that the technical knowledge required to make them is equally available to all producers. This was the case for most textiles, garments, leather articles, tennis and squash rackets, surgical instruments, and other items that were made in low-wage countries without the need for technical collaboration with high-wage country firms. But the range of such goods is limited and there seem to be none left, the production of which has not been transferred entirely to low-wage countries.

What this implies is that the technical knowledge needed to make tradable goods that are now produced in high-wage countries is not available to low-wage country producers. A specific period of economic history, in which low-wage countries could compete with high-wage countries in the manufacture of tradable goods because the requisite knowledge was available to all, is now over. Such goods are no longer made in high-wage countries, but are confined to low-wage countries and have a low value-added. High-wage countries' tradable manufactures are now all complex goods that require the specific technical knowledge of the high-wage country firms that make them. In other words, they are the results of the $R \& D$ of the high-wage country firms, and the technical knowledge generated by that $R \& D$ is proprietary, i.e., it is unavailable to others without the owning firms' agreement because it is protected by patents or is secret. Low-wage country firms can try to manufacture motor cars, television sets, printers, and dentists' drills, but, without access to the up-to-date, proprietary knowledge of the high-wage country firms, they can only make models that might have been competitive 10 or 20 years earlier, but are now technically backward. If these goods can be sold, it is at relatively low prices, i.e., they have a low value-added.

\section{Patterns of Industrialization}

\subsection{India and Autarky}

In theory, there are two ways of industrializing, apart from continuing along the present lines. One is through protection and some degree of autarky; the other is the way taken by several East Asian 
economies, i.e., collaboration with advanced economies' firms. For Pakistan, the latter is the only realistic course.

In practice, anything more than a minimal degree of autarky is ruled out by the international agreements to which Pakistan is bound and by the dependence on foreign aid. But it helps to understand how India became a fast growing industrial economy after decades of a high degree of autarky, whilst Pakistan, which has mostly tried to follow what were supposed to be its comparative advantages, has failed to create any comparable industrial structure.

From the start, India became protectionist with the aim of creating its own capital goods industries. Foreign trade and foreign investment were kept to what was needed to supply goods that could not realistically be produced in the country. State enterprises were considered necessary for the production of capital goods and requirements such as steel. The government's initial slogan was that the state should have the "commanding heights" of the economy, partly because it was unlikely at that stage that private firms would, of their own accord, start investing in the production of investment goods; they were more likely to confine themselves to consumer goods for which the market already existed. The government saw that industrialization requires scientists and engineers and it, therefore, put emphasis on the appropriate higher education, including institutions that are now comparable to the best universities in high-wage countries.

Such a system involved much administrative control over firms' decisions-including over foreign exchange, imports and exports, investment, bank credit, prices and so on-which certainly caused much inefficiency and corruption. Apart from that, keeping the country's industry technically behind the comparable industries of high-wage countries had an economic cost. India's planners had intended that the country's research institutions and firms should develop their own technical knowledge without sufficiently appreciating that they were unlikely to keep up with the R\&D of high-wage country firms, which had to compete among themselves in this respect. So, their lorries could have been well made, but their design was out of date (Wolf, 1982, p. 66).

This pattern of industrialization could have gone on indefinitely, with India always a few years behind the high-wage countries as regards technology, provided the rest of the world allowed the protectionism to continue and provided the country had enough primary products, tourism, and simple manufactures to export to avoid foreign exchange constraints becoming too severe. It had the drawback that the backward state of its 
technology would have prevented it from exporting manufactures with a high value-added.

In time, dissatisfaction with the course of the economy, especially its slow growth, the reasons for which are beyond the scope of this article, resulted in gradual abandonment of the semi-autarky, though protection is still there. But India has not yet acquired the export capability of China or Korea. It is not evident that its leaders wish to or know how to. But its investment in higher education has had the unexpected result of an information technology service export using digital communication and independent of physical transport. Added to that, there are the variety of services provided by Indian firms, such as processing medical insurance claims and keeping the books for large organizations in other countries.

Both the government and private firms are conscious of their need to acquire proprietary knowledge from high-wage country firms. One step was the suspension of international patent laws in the country, which seems to have given the pharmaceutical industry the chance to develop its generic business. Some of the bigger firms have also been taking over highwage country firms, which gives them access to the proprietary knowledge of those firms. With the higher education system it has developed, the economy has the scientists and engineers needed to absorb such proprietary knowledge as it can obtain. For a long time, development economists and multilateral institutions criticized the country for its socialism and protectionism and for wasting money on too much university-level education. Now that the economy has been growing rapidly, talk of comparative advantages and reducing emphasis on universities is no longer heard.

\subsection{East Asia and Collaboration}

East Asia's economies differ in many respects, but their successes have this in common, that their industries were mainly built up through collaboration with the firms of high-wage countries. The simplest form of such collaboration has been that of subcontracting in which a high-wage country firm that produces a complex good gives some technically simple components of that good to be made by a low-wage country firm. The wage cost is lowered and, if the high-wage country firm has full employment, this allows that country's firm to shift workers from making simple components that require little technical knowledge to making components that require more technical knowledge. To the extent that the firm has been constrained by the availability of workers, the constraint is relaxed. 
This does not require direct investment by the high-wage country firm. In some cases, it has been associated with foreign direct investment (FDI). This was the case for Indonesia, Malaysia, and Thailand in the 1980s, where firms from Europe, Japan, and the US invested in facilities for producing components or carrying out parts of their production processes. The two earliest such investments appear to have occurred in 1961 in Hong Kong, one being American and the other European (Wade, 1990, p. 94). Such investment spread to the other countries mentioned in the 1970s and 1980s. This success in attracting foreign investment was much praised, especially by institutions such as the World Bank and Asian Development Bank. In The East Asian Miracle published by the World Bank in 1993, the success of the East Asian economies is held up as an example of correct policies, without an understanding of the economic mechanisms involved.

South Korea's industrialization differed from these countries' in some respects. Its early attempts to attract foreign investment into export processing zones had had little success when the government decided to mend relations with Japan in 1965 with the Japan-Korea Normalization Agreement. Japan's economic planners and political leaders understood the way economic relations between the two countries could develop along the lines described above. They intended that Korea should allow Japan to concentrate increasingly on the technically most advanced production by taking over more and more technically simpler production. In the early stages, this included allowing most textiles manufacturing for the Japanese market to go to Korea. Instead of setting up trade barriers, they helped the process with technical support and financing. Castley (1997) recounts that Japan helped Korea become a producer of capital synthetic fibers while moving "into differentiated synthetic fibers, against which, in terms of quality and costs, Koreans were unable to compete" (p. 246-248). But the main form of industrialization through collaboration was by subcontracting the manufacture of specific components of Japanese goods.

In some of the subcontracting, the Korean firm made something that required no special technical knowledge that the firm did not already have, but much of the subcontracting depended on closer collaboration. The Japanese partner firm provided technical knowledge and training specific to the production arrangement between the two firms. A common complaint of Korean firms was that the technical knowledge and training they received did not go beyond what was needed for that production (see Cyhn, 2002, for examples). For a high-wage country firm providing proprietary knowledge and related training to a firm for subcontracting, there is the risk that the knowledge may be passed on to competitors or that the subcontracting partner eventually becomes able to use that 
knowledge to compete. One way to reduce the risk is to have a joint venture and, perhaps, to license the knowledge needed to the joint venture. This involves direct investment by the high-wage country firm, which thus finances the specialized capital equipment, and gives the firm a position in the management from where it can supervise the use of its proprietary knowledge. It also gives the low-wage country firm a long-term interest in the collaboration. Japanese firms entered into many such arrangements with Korean firms. Castley gives the number of direct investments by Japanese firms in Korea in the period 1962-79 as 617. The US came second with 97 (Castley, 1997, p. 154). This is not exactly the same as joint ventures, but, given the restrictions on foreign investments, which were not allowed to compete with domestic firms or to be for the domestic consumer goods market, it must have been close (Cyhn, 2002, pp. 88-90).

Such production allowed Korean firms to advance in their technical knowledge. It evolved from more or less simple production by the Korean partner to increasingly complex goods requiring the more advanced proprietary knowledge of the Japanese partner. It was partly a process of growing trust and partly because the collaboration could broaden to include more items. In this form of collaboration, the Japanese firm always kept the most advanced proprietary knowledge to itself, so that the production in Japan became more and more concentrated on the most advanced and technically complex components or processes.

Sometimes the collaboration evolved to "original equipment manufacture" (OEM), which means that the Korean firm produced the final good for another firm that sold it under its own brand name. A simple form of OEM in Pakistan has been the production of garments and towels, etc., for high-wage country firms, which then sell the articles under their brand names. In Korea, the OEM was mostly electronic goods and machinery. Even though the product of an OEM firm is good enough to be sold as the product of a firm with an established brand name, the OEM firm may not want to establish its own brand for two reasons. One is that doing so is costly and uncertain. It can be more uncertain if it antagonizes the partner firm and that creates problems with suppliers, distributors, and banks. The second is that the OEM firm is unlikely to have had the R\&D capacity to design the good and is, therefore, unlikely to be able to carry out the $R \& D$ to improve it and bring out new models. In that case, the venture to establish a brand name will be a one-shot affair.

Korean firms followed two other patterns of industrialization. One, which was temporary, was to use the technical knowledge the firms had 
access to independently of foreign partners to produce versions of goods that were technically backward compared to those produced by high-wage country firms and to sell them cheaply. This is like the Indian production of technically backward goods using the technical knowledge available in India, except that it was for export. Korean firms sold low-quality stereo sets in some Asian markets and microwave ovens that did not last in the US at correspondingly low prices. This was a minor aspect of the economy's exports, though such cheap, low-quality versions of goods may have been a more important part of the supply to the domestic market, which was protected against import competition and domestic production by foreigners.

More important for the future, and also harder to distinguish from the acquisition of technical knowledge through collaboration, was the success of some of the conglomerates, the chaebols, in building up their own capacity for R\&D and becoming as technically advanced as the firms of Japan and Western countries. In developing integrated circuit chips, in building ships, and in designing motor-cars, Korean firms have been well established for some time. But all these firms had long collaborated with Japanese firms and still do. Much of their R\&D may have been done separately from foreign firms with the intention of making the Korean firm independent, but, without detailed knowledge it is not possible to know when it was the one and when the other. The difficulty is illustrated by the litigation over patent infringements between Korean and American firms, although such disputes between Korean and Japanese firms seem not to arise or are settled with less trouble.

China is another economy whose government deliberately tried to obtain for it the most advanced technical knowledge and has been successful, though it cannot be discussed at length here. Like India, when it began to open to international trade it started with a wide range of industry that was technically backward compared to that of high-wage countries, and an education system that trained large numbers of scientists and engineers. But, more than India, the government used the low wage level and the abundance of technically trained workers to attract subcontracting. It attracted FDI to its export processing zones, to joint ventures for subcontracting, and to supply the domestic market. The biggest lure for foreign firms, in view of the population size and the speed at which income grew and industry was spreading, was the domestic market.

With these advantages came that of being able to use them to induce foreign firms to transmit proprietary knowledge to Chinese firms or to government institutions. The Chinese authorities showed that they were 
adept at this. Import restrictions allowed them to make access to the domestic market conditional on some arrangement with Chinese partners and, with that, the necessity of transferring proprietary knowledge. China's success as an exporter has partly been the result of the attraction of its subcontracting business, which has grown rapidly from simple firms with a few qualified staff or, perhaps, state enterprises in need of modernization, to some of the largest manufacturers of their types of products in the world. From the start it was clear that the government intended to acquire for the economy the most advanced technical knowledge it could in all the manufacturing activities that it wished to promote. The same was true of the Chinese firms that were to acquire the knowledge. The determination with which they went about this is indicated by the prominence in the news of accusations of violations of intellectual property rights and repeated criticism of the ways in which foreign firms wishing to invest in the country or set up joint ventures with Chinese firms have been required to yield proprietary knowledge.

\section{A Pattern of Industrialization for Pakistan}

The three examples of India, Korea, and China illustrate what can and cannot be done to industrialize beyond producing low-value-added goods. To begin with what cannot be done, there have been changes in international agreements and their enforcement. The "rules of the game" have changed. On paper, they prohibit the various devices that countries have used to give advantages to their own industries or to create incentives that are not the ordinary ones of the free market, although tariffs are still allowed as far as agreed. Pakistan has lost the power to use tariffs to encourage FDI in the country's industry or to provide a high level of protection to domestic industry by agreeing to relatively low tariffs, mostly 5-20 percent. The exception is motor vehicles and parts, although it is unlikely that that can develop into an industry that will export or be competitive with imports in the foreseeable future.

Various other methods that have been used by the East Asian economies and even by Western economies at various stages of their past, are also now prohibited. Export subsidies by the state have been widely used for manufactures and are now banned. These include state subsidies of firms, of bank financing to lower interest rates and research subsidies. How hard it can become to identify such subsidies is shown by the disputes between aircraft makers of the US and Europe. Another device that can be counted as a subsidy is the multiple exchange rate system, which, in any case, the International Monetary Fund (IMF) prohibits. That, 
too, can be hard to spot, even by the country, and the IMF has a book of rules as to what constitutes multiple exchange rates. Large conglomerate firms can cross-subsidize, using the profits from one activity to subsidize an export at a loss, perhaps with the connivance of the state, which extends concessional financing apparently unrelated to the export or grants contracts. Against this are the anti-dumping rules, which can be quickly invoked and often are, not always justifiably. Performance targets, by which the state gave rewards or penalties to firms according to whether they reached agreed export targets or not, were extensively used in Korea and are also prohibited.

All these methods and others were used frequently and with success, but are no longer available to Pakistan. The rules and their application have been made stricter over the last two decades, and a country that has little bargaining power is forced to observe them. Those who have bargaining power can bend them and often do so through bilateral trade agreements that are outside the official framework of the World Trade Organization (WTO). ${ }^{4}$ In practice, observing the rules, obtaining redress when others violate them, circumventing them where possible, and navigating the many bilateral and multilateral agreements require expertise. Countries that take their international trade seriously have large departments in their ministries with hundreds, even thousands of experts, and bring teams of lawyers to the WTO and other organizations to fight their cases. In this respect, Pakistan has surprisingly little.

What Pakistan can do is limited. The principle behind the WTO's rules is that private firms should compete on equal terms. It takes no account of differences in the ability to compete caused by differences in the access to up-to-date technical knowledge, which cannot be offset by lower wages; when lower wages allow competition, the rules allow deviation from the principle. Practically any manufacture that Pakistan can produce that competes with something produced in high-wage countries risks discrimination through tariffs, bilateral agreements, and accusations of dumping. Where there are rival low-wage country exporters, Pakistan is among the least favored, despite its long record of having tried to abide by the advice of its foreign advisors that it should follow its comparative advantages. When the European Union recently proposed granting Pakistan trade concessions for two years on textiles and some ethanol products, it had to overcome objections by Bangladesh and India, among others. These concessions seem to be related to the floods of 2010 and the

\footnotetext{
${ }^{4}$ Haque (2009) gives an overview of how Pakistan is affected by such trading arrangements.
} 
hope is that they will help improve relations ("Brussels to boost Pakistan," 2012). Approval is expected soon.

Subcontracting manufactured components for foreign firms has the advantage that it is difficult to discriminate against the products in the way that textiles and ethanol have been discriminated against because they are parts of other products. In the long run, its advantage is that stable subcontracting relations can expand to the production of more complex articles for which the Pakistani subcontractors get more value-added and to joint ventures with investment by the foreign partners. The foregoing discussion, especially the description of Korea's industrialization, gives a brief account of how varied subcontracting can be and how far it can be taken by diligence and reliability.

There should be no expectations of FDI at first. The FDI that has come into the country has mostly gone toward taking over banks and other existing firms, some retail, and setting up telecommunication services-the easy pickings-rather than to setting up new manufacturing capacity. It is also not certain how much is genuinely foreign and how much Pakistani capital returned to take advantage of favorable terms. Ventures into subcontracting will have to start virtually from scratch, which is to say they will have to decide what they can produce and for which foreign firms they can produce it, and then obtain the contracts. From that, they must establish a partnership that lasts.

One prerequisite is that the firm should have enough technically qualified people. Subcontracting demands that the product meet specifications and that changes of specification and design be made quickly to meet the needs of the foreign partner. Speed, punctuality, and quality control have to be ensured, and workers' technical qualifications have to be adequate to this. If, in producing the subcontracted article, the firm can suggest improvements or additional articles that it is able to produce, the collaboration is likely to improve over the long run.

Pakistan's disadvantage is the effect that long neglect has had on the education system. At present, the government-both at the center and in the provinces-lacks the revenue to improve higher education as much as needed. In part, this is the consequence of trade liberalization since import duties were one of the main revenue sources, and replacing the loss is practically and politically difficult. Both the numbers of people being trained in the natural sciences and engineering at university level and the quality of their training are lacking compared to other countries. Families who can, send their children abroad for their education, but, of those who 
study the natural sciences and engineering, many remain abroad. In addition, it is now accepted practice that the US and Europe recruit people in the country with the right qualifications, which saves them the education costs. Industrialization at present does not require large numbers of people with higher degrees, so the shortfall may not be so great as to prevent subcontractors with good prospects from obtaining the qualified people they need. It may also be possible to attract back some Pakistanis working abroad. At the beginning of its industrialization, about 80 percent of Korea's students abroad stayed abroad. But when industrialization got going, many returned with improved qualifications, experience and, possibly, technical information that their new employers would not have obtained easily otherwise. There is a possibility of a virtuous cycle.

Some other requirements for subcontracting to become a major industrial activity need only be mentioned quickly. One is that there should be suitable infrastructure, reliable power supplies, good transportation, fast telecommunications, and security, etc. These are most easily assured in industrial zones near ports and airports, but it has to be expected that much subcontracting will, at the start, come from existing producers who may be anywhere. The question of whether any special legislation is needed ought to be studied, but there should be an office for resolving disputes impartially and quickly with the purpose of helping maintain stable relations. To the extent that it resolves disputes without the parties having recourse to courts or international dispute resolution instances, it will help improve confidence in the country. Complementing this would be an institution representing subcontractors and, at the same time, giving them the means to advertise abroad and to safeguard their reputation by dealing with members for actions that hurt their standing.

The question that arises is how to induce firms to look for subcontracting opportunities when practically all exports get all the advantages that can be offered, and manufacturers in the country have done little in this respect so far. Pakistan does not have a Japan as did Korea; it does not have the numbers of well educated scientists and engineers or offer a vast market as do China and India; and it cannot provide the comforts and climate by which Indonesia, Malaysia, Thailand and others attract foreigners. This means that establishing a subcontracting industry of any size will be a gradual process. Subcontracting will grow slowly for a long time before it becomes a major source of income. If it succeeds, there is the prospect of moving into the production of goods with more valueadded at some time in the future. There seem to be no obvious alternatives. 


\section{References}

Balassa, B. A., \& Associates. (1971). The structure of protection in developing countries. Baltimore, MD: Johns Hopkins Press/International Bank for Reconstruction and Development and Inter-American Bank.

Brussels to boost Pakistan with trade concessions. (2012, January 31). Financial Times, p. 6.

Castley, R. (1997). Korea's economic miracle: The crucial role of Japan. Basingstoke, UK: Macmillan.

Chaudhry, T. T. (2005). Industrial clusters in developing countries: A survey of the literature. Lahore Journal of Economics, 10(2), 15-34.

Cyhn, J. W. (2002). Technology transfer and international production: The development of the electronics industry in Korea. Cheltenham, UK: Edward Elgar.

Government of Pakistan. (1957). Report of the fact finding committee on handlooms. Karachi, Pakistan: Author.

Gresser, E. (2002). America's hidden tax on the poor: The case for reforming US tariff policy (Policy report). Washington, DC: Progressive Policy Institute.

Haque, I. (2009, September). The rise of bilateralism in trade and its implications for Pakistan. Paper presented at the Lahore School of Economics' Fifth Annual Conference on the Management of the Pakistan Economy, Lahore, Pakistan.

Krueger, A. O. (1972). Evaluating restrictionist trade regimes: Theory and measurement. Journal of Political Economy, 80(1), 48-62.

Nadvi, K. (1999). Collective efficiency and collective failure: The response of the Sialkot surgical instrument clusters to global quality pressures. World Development, 27(9), 1605-1626.

Wade, R. (1990). Governing the market: Economic theory and the role of government in East Asian industrialization. Princeton, NJ: Princeton University Press. 
Wolf, M. (1982). India's exports. Washington, DC: World Bank/Oxford University Press.

World Bank. (1993). The East Asian miracle: Economic growth and public policy. Washington, DC: Oxford University Press.

Zaidi, S. A. (1999). Issues in Pakistan's economy. Karachi, Pakistan: Oxford University Press. 